\title{
PENGARUH PRESSURE, OPPORTUNITY, RASIONALIZATION DAN CAPABILITY TERHADAP KECENDERUNGAN KECURANGAN AKUNTANSI (FRAUD)
}

\section{THE INFLUENCE OF PRESSURE, OPPORTUNITY, RASIONALIZATION AND CAPABILITY ON ACCOUNTING FRAUD TRENDS}

\author{
I.C. Kusuma, R. Nurfitri, M.N. Mukmin
}

Program Studi Akuntansi Fakultas Ekonomi Universitas Djuanda Bogor

Jl. Tol Ciawi No. 1, Kotak Pos 35, Kode Pos 16720, Telp/Fax : (0251) 8245155

Email : indra.cahya.kusuma@unida.ac.id rachminf15@gmail.com

\begin{abstract}
Fraud described any deliberate fraud attemps, which were intended to take the property or rughts of another person or party. The purpose of this study was to examine the effect of pressure, opportunity, rasionalization and capability on the tendency of accounting fraud (fraud). The population in this study is the Office, agency and office in Sukabumi City. Sampling of this study uses purposive sampling method with criteria of employees who are in the financial subsection or who are responsible for financial management of each department, agency and office. The data in this study were obtained by distributing questionnaires to 88 respondents in 16 offices, 3 agencies and 4 offices in Sukabumi City. Testing hypotheses and instrument research using multiple linear regression analysis tools. The results of this study prove that: pressure, opportunity and capability affect the tendency of accounting fraud (fraud), while rationalization does not affect the tendency of accounting fraud (fraud).
\end{abstract}

Keyword: pressure, opportunity, rasionalization, capability and fraud

\begin{abstract}
ABSTRAK
Fraud menggambarkan setiap upaya penipuan yang disengaja, yang dimaksudkan untuk mengambil harta atau hak orang atau pihak lain. Tujuan penelitian ini adalah untuk menguji pengaruh pressure, opportunity, rasionalization dan capability terhadap kecenderungan kecurangan akuntansi (fraud). Populasi dalam penelitian ini adalah Dinas, badan dan kantor di Kota Sukabumi. Pengambilan sampel penelitian ini menggunakan metode purposive sampling dengan kriteria pegawai yang berada pada subbagian keuangan atau yang bertanggungjawab terhadap pengelolaan keuangan pada masing - masing dinas, badan dan kantor. Data dalam penelitian ini diperoleh dengan cara menyebarkan kuesioner kepada 88 responden di 16 Dinas, 3 badan dan 4 kantor di Kota Sukabumi. Pengujian hipotesis dan instrument penelitian menggunakan alat analisis regresi linier berganda. Hasil penelitian ini membuktikan bahwa: pressure, opportunity dan capability berpengaruh terhadap kecenderungan kecurangan akuntansi (fraud), sedangkan rasionalization tidak berpengaruh terhadap kecenderungan kecurangan akuntansi (fraud).
\end{abstract}

Kata Kunci : pressure, opportunity, rasionalization, capability dan fraud 


\section{PENDAHULUAN}

Kecurangan saat ini sedang menjadi topik utama dalam setiap pemberitaan di media, baik media cetak maupun media elektronik. Menurut Transparency International pada tahun 2017, Indonesia menempati peringkat 96 sebagai Negara terkorup di Dunia, hasil tersebut seharusnya menjadi bahan evaluasi untuk pemerintah Indonesia agar melakukan pencegahan terhadap kesempatan melakukan kecurangan. Adapun tabel data korupsi berdasarkan sektor, tahun 2017 yang dirilis oleh ICW adalah:

Tabel 1: Kasus Korupsi Berdasarkan Sektor

\begin{tabular}{lll}
\hline Sektor & $\begin{array}{l}\text { Jumlah } \\
\text { Kasus }\end{array}$ & $\begin{array}{l}\text { Kerugian } \\
\text { Negara }\end{array}$ \\
\hline Anggaran Desa & 98 & $39,3 \mathrm{M}$ \\
Pemerintahan & 55 & $255 \mathrm{M}$ \\
Pendidikan & 53 & $81,8 \mathrm{M}$ \\
Transportasi & 52 & $985 \mathrm{M}$ \\
Sosial & 40 & $41,1 \mathrm{M}$ \\
Kemasyarakatan & &
\end{tabular}

Sumber : Indonesia Corruption Watch 2017

Fenomena masalah yang terjadi di Kota Sukabumi adalah Kasus yang telah diselidiki berdasarkan informasi dari news.okezone.com, pada tahun 2017 yaitu kasus Tindak Pidana Korupsi di Kota Sukabumi yang melibatkan mantan Kepala Badan Penanggulangan Bencana Daerah (BPBD). Kerugian Negara akibat hal itu yaitu mencapai Rp263.789.390. Pos Kota (2017), sekitar 425 juta lebih uang Negara dari hasil tindak korupsi berhasil diselamatkan Kejaksaan Negeri Kota Sukabumi. Besaran uang Negara tersebut, berasal dari kasus korupsi penyalahgnaan dana bantuan pemerintah Dirjen Sarana dan Prasarana Kementrian Pertanian RI dalam Program Unit Pengolahan Pupuk Organik (UPPO). Selama tahun terakhir 2017 Kejari Kota Sukabumi menangani 5 perkara tindak pidana korupsi dalam tahap penyidikan, 9 perkara tahap penuntutan dan 3 perkara yang sudah di eksekusi.

Berdasarkan beberapa kasus diatas kecurangan sering terjadi pada dinas pemerintahan. ACFE (2009), Kecurangan (fraud) sebagai tindakan penipuan yang dibuat oleh seseorang atau badan yang mengetahui bahwa kekeliruan tersebut dapat mengakibatkan kerugian kepada individu atau entitas lain. Arens dkk, (2006:430)

Widjaja (2013:228) kecurangan akuntansi dapat terjadi karena adanya tekanan, kesempatan dan sikap/rasionalisasi, atau disebut juga fraud triangle. Tindakan kecurangan dapat dilakukan oleh individu/pejabat pemerintahan karena adanya beberapa kondisi seperti Tekanan (Pressure), Peluang (Opportunity), Rasionalitas (Rationalitazation) dan Kemampuan (Capability). Kondisi-kondisi tersebut dapat disebut juga dengan fraud diamond. Fraud diamond merupakan bentuk penyempurnaan dari fraud triangle.

Ruankew 2016), Tekanan (Pressure) Setiap pelaku harus menghadapi beberapa jenis tekanan untuk melakukan penipuan. Tekanan yang dirasakan didefinisikan sebagai motivasi yang mengarahkan pelaku untuk terlibat dalam perilaku yang tidak etis misalnya tekanan dari atasan , keluarga, atau organisasi. Ruankew (2016:475), Kesempatan (Opportunity) elemen kedua yang diperlukan untuk terjadi kecurangan yaitu Peluang/Kesempatan . Peluang yang ada di organisasi memiliki dampak besar pada keputusan individu untuk melakukan kecurangan. Peluang dapat terjadi karena pengendalian internal yang lemah, pengawasan manajemen yang kurang baik atau melalui penggunaan posisi.. Sihombing (2014:29), Hampir semua Fraud dilatarbelakangi oleh Rationalization. Rasionalisasi membuat seseorang yang awalnya tidak ingin melakukan Fraud pada akhirnya 
melakukannya. Rasionalisasi merupakan suatu alasan yang bersifat pribadi (karena ada faktor lain) dapat membenarkan perbuatan walaupun perbuatan itu sebenarnya salah.

Kemampuan (Capability), menurut Wolfe dan Hermanson (2004) berpendapat bahwa posisi seseorang dalam organisasi dapat memberikan kemampuan dalam memanfaatkan kesempatan untuk melakukan penipuan. Menurut Ruankew (2016:475), Posisi atau fungsi seseorang dalam perusahaan dapat memberinya kemampuan untuk membuat atau memanfaatkan peluang untuk melakukan kecurangan.

Menurut penelitian Yudishtira (2017), Susandra (2017) menyatakan bahwa fraud triangle menjadi faktor pendorong seseorang melakukan kecurangan (fraud. Sedangkan penelitian yang dilakukan Edi (2017), Shelton (2004), Sihombing (2014) hasil penelitiannya adalah bahwa capability berpengaruh terhadap kecurangan akuntansi (fraud).

\section{METODE PENELITIAN}

Objek penelitian ini adalah 17 Dinas, 5 Badan dan 2 Kantor yang berada di Kota Sukabumi. Penelitian ini adalah penelitian kuantitatif, metode penelitian yang digunakan dalam penelitian ini adalah metode deskriptif dan asosiatif yaitu merupakan penelitian yang berkaitan dengan pertanyaan terhadap keberadaan variabel mandiri, baik hanya satu variabel ataupun lebih, dan pengertian asosiatif adalah suatu penelitian yang bersifat menanyakan hubungan antara dua variabel atau lebih. (Sugiyono, 2013 : 59).

Berdasarkan karakteristiknya, jenis data yang digunakan dalam penelitian ini adalah data kuantitatif yaitu data yang berbentuk angka atau data kualitatif yang diangkakan/diberi scoring (Sugiyono, 2013 : 25). Data yang dikumpulkan adalah data primer dan sekunder.. Adapun teknik yang digunakan untuk pengambilan sampel dalam penelitian ini adalah teknik purposive sampling. Menurut Sugiyono
(2013 : 126) teknik purposive sampling adalah teknik penentuan sampel dengan pertimbangan atau kriteria tertentu.

\section{METODE ANALISIS DATA}

Regresi berganda digunakan untuk meramalkan bagaimana perubahan nilai variabel dependen, bila 2 (dua) atau lebih variabel independen dinaik turunkan nilainya (Sugiyono, 2008 : 277). Adapun persamaan regresi berganda dalam penelitian ini adalah sebagai berikut:

$$
\begin{gathered}
Y=a+\beta_{1} X_{1}+\beta_{2} X_{2}+\beta_{3} X_{3}+\beta_{3} X_{4} \\
+\varepsilon
\end{gathered}
$$

Keterangan:

$\mathrm{Y}=$ variabel dependen Kecenderungan Kecurangan Akuntansi

$a=$ bilangan konstanta

$\mathrm{X}_{1}=$ Pressure

$\mathrm{X}_{2}=$ Opportunity

$\mathrm{X}_{3}=$ Rasionalization

$\mathrm{X}_{3}=$ Capability

$B_{1}=$ koefisien regresi variabel Pressure

$\beta_{2}=$ koefisien regresi variabel

Opportunity

$\beta_{3}=$ koefisien regresi variabel

Rasionalization

$\beta_{4}=$ koefisien regresi variabel Capability

$\varepsilon \quad=$ faktor lain yang tidak diteliti

\section{Koefisien Korelasi Berganda}

Untuk mengetahui bagaimana keeratan hubungan antara Pressure, Opportunity, Rasionalization dan Capability dengan Kecenderungan Kecurangan Akuntansi pada SKPD Kota Sukabumi, maka digunakan rumus sebagai berikut (Sugiyono, $2000: 218$ ) :

$$
r X_{i} Y=\frac{n \sum X_{i} Y-\left(\sum X_{i}\right)\left(\sum Y\right)}{\sqrt{n \sum X_{i}^{2}-\left(\sum X_{i}\right)^{2} \sqrt{n \sum Y^{2}-\left(\sum Y\right)^{2}}}}
$$

Dari rumus analisis korelasi tersebut di atas, maka akan diperoleh nilai $r$ yang besarnya antara $-1, \quad 0$ sampai +1 . Notasi ini menunjukkan korelasi atau hubungan antar variabel-variabel yang diuji dalam penelitian. 
Tabel 4 Interpretasi Terhadap Nilai r Hasil Analisis Korelasi

\begin{tabular}{ll}
\hline Interval Nilai r & Interpretasi \\
\hline $0,001-0,200$ & Sangat Lemah \\
$0,201-0,400$ & Lemah \\
$0,401-0,600$ & Cukup Kuat \\
$0,601-0,800$ & Kuat \\
$0,801-1,000$ & Sangat Kuat \\
\hline
\end{tabular}

Sumber : Sugiyono, 2012

\section{Analisis Koefisien Determinasi}

Analisis koefisien determinasi digunakan untuk mengetahui persentase sumbangan pengaruh variabel independen secara bersama-sama terhadap variabel dependen (Priyatno, 2011 : 251). Koefisien determinasi dihitung dengan rumus sebagai berikut:

keterangan:

$$
\mathrm{KD}=r^{2} \times 100 \%
$$

$\begin{aligned} \mathrm{KD} & =\text { koefisien determinasi } \\ r & =\text { koefisien korelasi }\end{aligned}$

\section{Pengujian Hipotesis}

1. Uji F

Uji F digunakan untuk mengetahui variabel independen secara simultan terhadap variabel dependen (Priyatno, $2011: 258$ ).

a. Perumusan hipotesis Statistik

Adapun rumusan hipotesis sebagai berikut:

Ho $\quad: \quad \beta i=0$ : $\quad$ Tidak

terdapat pengaruh signifikan Pressure, Opportunity, Rasionalization dan Capability terhadap Kecenderungan Kecurangan Akuntansi pada SKPD Kota Sukabumi.
$\mathrm{Ha}$ :

$$
\beta i=0:
$$
Terdapat
pengaruh signifikan Pressure,
Opportunity, Rasionalization dan
Capability terhadap Kecenderungan
Kecurangan Akuntansi pada SKPD Kota Sukabumi.

b. Rumus uji $\mathrm{F}$

Adapun rumus $\mathrm{Uji} F$ adalah sebagai berikut:

Keterangan:

$$
F=\frac{R^{2} / K}{\left(1-R^{2}\right)(n-K-1)}
$$

$$
\begin{aligned}
& \mathrm{F} \quad=\text { koefisien } \mathrm{F} \\
& \mathrm{R} 2 \quad=\text { koefisien korelasi }
\end{aligned}
$$

$\mathrm{n} \quad=$ jumlah sampel

$\mathrm{K}=$ jumlah variabel independen

c. Kriteria keputusan uji $\mathrm{F}$

a. Bila $F_{\text {hitung }}$ lebih kecil dari atau sama dengan $F_{\text {tabel }}\left(F_{\text {hitung }} \leq F_{\text {tabel }}\right)$ pada $\alpha=0,05$ maka Ho diterima dan Ha ditolak, artinya tidak terdapat pengaruh signifikan Pressure $\left(\mathrm{X}_{1}\right)$, Opportunity $\left(\mathrm{X}_{2}\right)$, Rasionalization $\left(\mathrm{X}_{3}\right)$ dan Capability $\left(\mathrm{X}_{4}\right)$ secara simultan terhadap Kecenderungan Kecurangan Akuntansi (Y) SKPD Kota Sukabumi.

b. Bila $F_{\text {hitung }}$ lebih besar dari $F_{\text {tabel }}\left(F_{\text {hitung }}>\right.$ $F_{\text {tabel }}$ ) pada $\alpha=0,05$ maka Ho ditolak dan $\mathrm{Ha}$ diterima, artinya terdapat pengaruh signifikan Pressure $\left(\mathrm{X}_{1}\right)$, Opportunity $\left(\mathrm{X}_{2}\right)$, Rasionalization $\left(\mathrm{X}_{3}\right)$ dan Capability $\left(\mathrm{X}_{4}\right)$ secara simultan terhadap Kecenderungan Kecurangan Akuntansi (Y) SKPD Kota Sukabumi.

2. Ujit

Uji t digunakan untuk mengetahui pengaruh variabel independen secara parsial terhadap variabel dependen (Priyatno, 2011 : 252).

a. Perumusan hipotesis Statistik

Adapun rumusan hipotesis sebagai berikut:

- Pressure terhadap Kecenderungan Kecurangan Akuntansi:

$\mathrm{Ho}_{1}: \quad \beta_{1}=0$ : $\quad$ berarti

Pressure $\left(\mathrm{X}_{1}\right)$ tidak berpengaruh signifikan terhadap Kecenderungan Kecurangan Akuntansi (Y) pada SKPD Kota Sukabumi.

$\mathrm{Ha}_{1}: \quad \beta_{1}=0$ : $\quad$ berarti

Keefektifan Pressure $\left(\mathrm{X}_{1}\right)$ berpengaruh signifikan terhadap Kecenderungan Kecurangan Akuntansi (Y) pada SKPD Kota Sukabumi.

-Opportunity terhadap Kecenderungan Kecurangan Akuntansi:

$\mathrm{Ho}_{2}: \quad \beta_{2}=0$ : berarti

Opportunity $\left(\mathrm{X}_{2}\right)$ tidak berpengaruh signifikan terhadap Kecenderungan Kecurangan Akuntansi (Y) pada SKPD Kota Sukabumi.
$\mathrm{Ha}_{2}: \quad \beta_{2}=0: \quad$ berarti
Opportunity $\left(\mathrm{X}_{2}\right) \quad$ berpengaruh signifikan terhadap Kecenderungan 
Kecurangan Akuntansi (Y) pada SKPD Kota Sukabumi.

- Rasionalization terhadap Kecenderungan Kecurangan Akuntansi:

$\mathrm{Ho}_{3}: \quad \beta_{3}=0$ : berarti

Rasionalization $\left(\mathrm{X}_{3}\right)$ tidak berpengaruh signifikan terhadap Kecenderungan Kecurangan Akuntansi (Y) pada SKPD Kota Sukabumi.

Ha3 : $\quad \beta_{3}=0$ : $\quad$ berarti

Rasionalization $\quad\left(\mathrm{X}_{3}\right)$ berpengaruh signifikan terhadap Kecenderungan Kecurangan Akuntansi (Y) pada SKPD Kota Sukabumi.

- Capability terhadap Kecenderungan Kecurangan Akuntansi:

$\mathrm{Ho}_{4}: \quad \beta_{4}=0$ : $\quad$ berarti

Capability $\left(\mathrm{X}_{4}\right)$ tidak berpengaruh signifikan terhadap Kecenderungan Kecurangan Akuntansi (Y) pada SKPD Kota Sukabumi.

$\mathrm{Ha}_{4}: \quad \beta_{4}=0: \quad$ berarti

Capability $\left(\mathrm{X}_{3}\right)$ berpengaruh signifikan terhadap Kecenderungan Kecurangan Akuntansi (Y) pada SKPD Kota Sukabumi.

Rumus uji $\mathrm{t}$

Adapun rumus yang digunakan adalah sebagai berikut :

$$
t=\frac{r(n-2)}{\left(1-r^{2}\right)}
$$

keterangan :

\begin{tabular}{cccc}
\hline No & Variabel & Nilai Rata-rata & Keterangan skor Tanggapan \\
\hline 1 & Pressure & 3,83 & Setuju \\
2 & Opportunity & 3,78 & Setuju \\
3 & Rasionalization & 3,02 & Kurang setuju \\
4 & Capability & 3,77 & Setuju \\
5 & Kecenderungan kecurangan & 2,95 & Kurang setuju \\
& Akuntansi (fraud) & & \\
\hline
\end{tabular}

Data diolah, 2018

Berdasarkan tabel 5, dapat disimpulkan bahwa jawaban responden untuk variabel pressure memiliki nilai rata-rata yaitu 3,83 dengan keterangan rata-rata setuju dengan pernyataan yang diajukan dalam kuesioner. Jawaban responden untuk varibel opportunity memiliki nilai rata-rata yaitu 3,78 dengan keterangan rata-rata jawaban responden setuju dengan pernyataan yang diajukan dalam kuesioner. Jawaban $\mathrm{t}=\mathrm{t}_{\text {hitung }}$ yang selanjutnya

dibandingkan dengan $t_{\text {tabel }}$

$\mathrm{r} \quad=$ koefisien

$\mathrm{n} \quad=$ jumlah data atau observasi

c. Kriteria keputusan uji $\mathrm{t}$

- Untuk Pressure $\left(\mathrm{X}_{1}\right)$, Opportunity $\left(\mathrm{X}_{2}\right)$, Rasionalization $\left(\mathrm{X}_{3}\right)$, dan Capability $\left(\mathrm{X}_{4}\right)$ bila thitung lebih kecil dari atau sama dengan $\mathrm{t}_{\text {tabel }}\left(\mathrm{t}_{\text {hitung }} \leq \mathrm{t}_{\text {tabel }}\right)$ pada $\alpha=0,05$ maka Ho diterima dan Ha ditolak, artinya Pressure $\left(\mathrm{X}_{1}\right)$, Opportunity $\left(\mathrm{X}_{2}\right)$, Rasionalization $\left(\mathrm{X}_{3}\right)$, dan Capability $\left(\mathrm{X}_{4}\right)$ tidak mempunyai pengaruh signifikan terhadap Kecenderungan Kecurangan Akuntansi (Y) pada SKPD Kota Sukabumi. Sedangkan apabila $t_{\text {hitung }}$ lebih besar dari $t_{\text {tabel }}$ ( $t_{\text {hitung }}>$

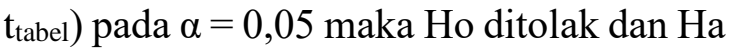
diterima, artinya Pressure $\left(\mathrm{X}_{1}\right)$, Opportunity $\left(\mathrm{X}_{2}\right)$, Rasionalization $\left(\mathrm{X}_{3}\right)$, dan Capability $\left(\mathrm{X}_{4}\right)$ berpengaruh signifikan terhadap Kecenderungan Kecurangan Akuntansi (Y) pada SKPD Kota Sukabumi.

\section{HASIL DAN PEMBAHASAN}

\section{Tanggapan Responden}

Berdasarkan rekapitulasi dari masingmasing jawaban responden, dibawah ini akan dijelaskan rekapitulasi dari keseluruhan tanggapan atau jawaban responden, yaitu sebagai berikut:

Tabel 5 : Tanggapan Responden

responden untuk variabel rasionalization memiliki nilai skor jawaban responden ratarata yaitu 3,02 dengan keterangan rata-rata kurang setuju dengan pernyataan yang diajukan dalam kuesioner. Jawaban responden untuk variabel capability memiliki nilai rata-rata yaitu 3.77 dengan keterangan rata-rata jawaban responden setuju dengan pernyataan yang diajukan dalam kuesioner. Dan untuk jawaban 
responden variabel kecenderungan kecurangan akuntansi (fraud) memiliki nilai rata-rata yaitu 3,17 dengan jawaban rata-rata responden kurang setuju dengan pernyataan yang diajukan dalam kuesioner. Sehingga dapat disimpulkan bahwa

\section{Uji Validitas}

Pressure, Opportunity, Rasionalization dan Capability akan mempengaruhi Kecenderungan kecurangan akuntansi (fraud) pada SKPD Kota Sukabumi.

Tabel 6: Rekapitulasi Uji Validitas

\begin{tabular}{ccccc}
\hline No & Variabel & $\mathbf{r}_{\text {hitung }}$ & $\mathbf{r}_{\text {kritis }}$ & Kesimpulan \\
\hline 1 & Pressure & 0,647 & 0,3 & Valid \\
2 & Opportunity & 0,651 & 0,3 & Valid \\
3 & Rasionalization & 0,629 & 0,3 & Valid \\
4 & Capability & 0,602 & 0,3 & Valid \\
5 & Kecenderungan Kecurangan & 0,795 & 0,3 & Valid \\
& Akuntansi (Fraud) & & & \\
\hline
\end{tabular}

Sumber : Data diolah, 2018

Berdasarkan tabel 4.59 nilai rata-rata dari variabel pressure yaitu 0,647, variabel opportunity yaitu 0,651 , variabel rasionalization yaitu 0,629 , variabel capability yaitu 0,602 dan varibel kecenderungan kecurangan akuntansi (fraud) yaitu 0,795, maka semua dinyatakan valid karena nilai hitung lebih dari nilai $\mathrm{r}_{\text {kritis }}$ yaitu lebih dari 0,3 maka dapat disimpulkan bahwa semua instrument pernyataan valid dan layak digunakan sehingga pernyataan instrument dalam penelitian ini dapat mengukur apa yang seharusnya diukur yaitu mengenai kecurangan akuntansi pada SKPD Kota Sukabumi.

\section{Uji Reliabilitas}

Tabel 7: Rekapitulasi Uji Reliabilitas

\begin{tabular}{lcccc}
\hline No & Item & Cronchbach's Alpha item Total Correlation & $\mathbf{r}_{\text {kritis }}$ & Kesimpulan \\
\hline 1 & Pressure & 0,771 & 0,6 & Reliabel \\
2 & Opportunity & 0,888 & 0,6 & Reliabel \\
3 & Rasionalization & 0,878 & 0,6 & Reliabel \\
4 & Capability & 0,798 & 0,6 & Reliabel \\
5 & Kecenderungan & 0,946 & 0,6 & Reliabel \\
& Kecurangan & & & \\
$\quad$ Akuntansi (fraud) & & &
\end{tabular}

Berdasarkan tabel rekapitulasi uji reliabilitas tersebut dengan nilai rata-rata item pernyataan variabel pressure 0,771 , Opportunity 0,88, Rasionalization 0,878, Capability 0,798, dan Kecenderungan Kecurangan Akuntansi (fraud) 0,946, semua nilai tersebut menunjukan lebih besar dari 0,6 bermakna bahwa semua item pernyataan dalam penelitian ini reliabel tidak akan berubah meskipun dilakukan pada penelitian pada waktu dan tempat yang berbeda.

\section{Uji Asumsi Klasik}

\section{Uji Normalitas}

Hasil pengujian telah memperlihatkan grafik histogram dapat disimpulkan bahwa grafik histogram memberikan pola distribusi normal dengan kurva berbentuk lonceng sedangkan, dengan mengamati grafik normal probability plot, dapat diketahui bahwa titik-titik menyebar sekitar garis dan mengikuti garis diagonal maka bermakna bahwa model regresi memenuhi asumsi normalitas sehingga data dapat digunakan dalam mengukur pengaruh pressure, opportunity rasionalization dan capability terhadap kecenderungan 
kecurangan akuntansi (fraud) pada SKPD Kota Sukabumi.

1. Metode Metode Statistikal One Sample

\section{Kolmogrov Smirnov}

Dari hasil pengujian One Sample Kolmogrov Smirnov nilai Asym. Sig. (2tailed) yaitu sebesar 0,189>0,05, jadi residual terdistribusi normal. Maka pengujian dengan menggunakan grafik histogram dan p-plot didukung dengan pengujian pengujian One Sample Kolmogrov Smirnov bermakna bahwa bahwa model regresi memenuhi asumsi normalitas sehingga data dapat digunakan dalam mengukur pengaruh pressure, opportunity rasionalization dan capability terhadap kecenderungan kecurangan akuntansi (fraud) pada SKPD Kota Sukabumi.

\section{Uji Multikolonieritas}

Berdasarkan hasil pengujian diperole hasil variable pressure memiliki nilai VIF yaitu 1,981, variable opportunity 1,726, variable rasionalization 1,139 dan variable capability 1,118. Sedangkan untuk nilai tolerance variable pressure 0,505 variabel opportunity 0,579 variabel rasionalization 0,878 dan variable capability 0,894 . Karena nilai VIF untuk keempat variabel independen kurang dari 10, dan nilai
Tolerance lebih dari 0,100 dari hasil pengujian tersebut bermakna bahwa bahwa model regresi dalam penelitian ini tidak terjadi gejala multikolonieritas atau non multikolonieritas sehingga dapat mengukur mengenai pengaruh pressure, opportunity rasionalization dan capability terhadap kecenderungan kecurangan akuntansi (fraud) pada SKPD Kota Sukabumi.

\section{Uji Heteroskedastisitas}

Hasil uji heteroskedastisitas, diperoleh bahwa titik-titik menyebar dengan pola yang tidak jelas diatas dan dibawah angka 0 pada sumbu Y, jadi dapat disimpulkan bahwa tidak terjadi masalah heterokedastisitas pada model regresi, bermakna bahwa model regresi tersebut layak digunakan untuk memprediksi kecenderungan kecurangan akuntansi (fraud) berdasarkan variabel pressure, opportunity, rasionalization dan capability.

\section{Analisis Regresi Berganda}

Analisis regresi linier berganda digunakan untuk mengetahui hubungan fungsional antara beberapa variabel bebas secara bersama-sama terhadap variabel terikat, dan juga untuk mengetahui jika nilai variabel independen dinaikan atau diturunkan nilainya.

Tabel 8: Regresi Linear Berganda

Coefficients $^{a}$

\begin{tabular}{|c|c|c|c|c|c|c|}
\hline \multirow{2}{*}{\multicolumn{2}{|c|}{ Model }} & \multicolumn{2}{|c|}{$\begin{array}{l}\text { Unstandardized } \\
\text { Coefficients } \\
\end{array}$} & \multirow{2}{*}{$\begin{array}{l}\text { Standardized } \\
\text { Coefficients } \\
\text { Beta }\end{array}$} & \multirow[t]{2}{*}{$\mathrm{T}$} & \multirow[t]{2}{*}{ Sig. } \\
\hline & & $\mathrm{B}$ & Std. Error & & & \\
\hline \multirow{5}{*}{1} & (Constant) & -10.737 & 4.052 & & -2.650 & .010 \\
\hline & Pressure (X1) & .370 & .113 & .303 & 3.271 & .002 \\
\hline & Opportunity (X2) & .193 & .092 & .181 & 2.098 & .040 \\
\hline & Rasionalization (X3) & .014 & .106 & .009 & .134 & .894 \\
\hline & Capability (X4) & 1.151 & .133 & .600 & 8.640 & .000 \\
\hline
\end{tabular}

a. Dependent Variable: Kecurangan Akuntansi (Y)

Sumber: Output pengolahan data dengan SPSS 25, 2018

Berdasarkan tabel 4.67 diatas diketahui Interpretasi dari regresi tersebut adalah bahwa nilai dari persamaan regresi yaitu sebagai berikut:

$Y=a+\beta_{1} X_{1}+\beta_{2} X_{2}+\beta_{3} X_{3}+\beta_{4} X_{4}+\varepsilon$

$Y=-10,737+0,370 X_{1}+0,193 X_{2}+0,014$

$\mathrm{X}_{3}+1,151 \mathrm{X}_{4}+\mathrm{e}$ sebagai berikut:

1. Konstanta sebesar -10,737; artinya jika $\mathrm{X}_{1}$ (Pressure) , $\mathrm{X}_{2}$ (Opportunity), $\mathrm{X}_{3}$ (Rasionalization) dan $\mathrm{X}_{4}$ (Capability) nilainya adalah 0 , maka besarnya $\mathrm{Y}$ 
(Kecenderungan

Kecurangan Akuntansi) nilainya negative sebesar 10,737 .

2. Koefisien regresi variabel $\mathrm{X}_{1}$ (Pressure) sebesar 0,$370 ; \quad$ artinya setiap peningkatan $\mathrm{X}_{1}$ (Pressure) sebesar 1 satuan, maka akan meningkatkan $\mathrm{Y}$ (Kecenderungan Kecurangan Akuntansi) sebesar 0,370 satuan, dengan asumsi variabel independen lain nilainya tetap.

3. Koefisien regresi variabel $\mathrm{X}_{2}$ (Opportunity) sebesar 0,193; artinya setiap peningkatan $\mathrm{X}_{2}$ sebesar 1 satuan, maka akan meningkatkan $\mathrm{Y}$ (Kecenderungan Kecurangan Akuntansi) sebesar 0,193 satuan, dengan asumsi variabel independen lain nilainya tetap.

4. Koefisien regresi variabel $\mathrm{X}_{3}$ (Rasionalization) sebesar 0,014; artinya setiap peningkatan $\mathrm{X}_{3}$ sebesar 1 satuan, maka akan meningkatkan $Y$
(Kecenderungan Kecurangan Akuntansi) sebesar 0,014 satuan, dengan asumsi variabel independen lain nilainya tetap.

5. Koefisien regresi variabel X4 sebesar 1,151 ; artinya setiap peningkatan $\mathrm{X} 4$ (Capability) sebesar 1 satuan, maka akan meningkatkan Y (Kecenderungan Kecurangan Akuntansi) sebesar 0,193 satuan, dengan asumsi variabel independen lain nilainya tetap.

\section{Korelasi}

\section{Korelasi Berganda}

Analisis koefisien korelasi berganda digunakan untuk mengetahui derajat kekuatan hubungan antara pressure, opportunity, rasionalization dan capability secara bersama-sama terhadap Kecenderungan Kecurangan Akuntansi (fraud) pada SKPD Kota Sukabumi. Adapun nilai koefisien korelasi dapat dilihat pada tabel 9 berikut ini:

Tabel 9: Koefesien Korelasi Berganda

\begin{tabular}{|c|c|c|c|}
\hline \multicolumn{4}{|c|}{ Model Summary ${ }^{b}$} \\
\hline Model & R Square & Adjusted R Square & $\begin{array}{l}\text { Std. Error of the } \\
\text { Estimate }\end{array}$ \\
\hline 1 & .724 & .706 & 4.403 \\
\hline
\end{tabular}

Berdasarkan tabel di atas diperoleh nilai $\mathrm{R}$ sebesar 0,851. Hal ini menunjukkan bahwa besarnya hubungan secara bersamasama variabel independen (Pressure, Opportunity, Rasionalization, dan Capability) memiliki hubungan yang sangat kuat. Hal ini karena nilai korelasi berada di rentang 0,801 - 1,000.

\section{Korelasi Parsial}

Analisis korelasi parsial digunakan untuk mengetahui derajat kekuatan hubungan antara masing-masing variabel terhadap Kecenderungan Kecurangan Akuntansi (fraud) pada SKPD Kota Sukabumi. Adapun nilai koefisien korelasi parsial dapat dilihat pada tabel 10 berikut ini: 
Tabel 10 Koefisien Korelasi Parsial

\begin{tabular}{|c|c|c|c|c|c|c|c|}
\hline & & & Pressure & Opportunity & $\begin{array}{l}\text { Rasionalizat } \\
\text { ion }\end{array}$ & Capability & $\begin{array}{l}\text { Kecendrungan } \\
\text { Kecurangan } \\
\text { Akuntansi } \\
\text { (Fraud) } \\
\end{array}$ \\
\hline \multirow{17}{*}{$\begin{array}{l}\text { Spe } \\
\text { arm } \\
\text { an's } \\
\text { rho }\end{array}$} & Pressure & Correlation & 1.000 & .648 & .350 & .325 & .618 \\
\hline & & Coefficient & & & & & \\
\hline & & Sig. (2-tailed) & .000 & . & .000 & .002 & .003 \\
\hline & & $\mathrm{N}$ & 69 & 69 & 69 & 69 & 69 \\
\hline & Opportunity & $\begin{array}{l}\text { Correlation } \\
\text { Coefficient }\end{array}$ & .648 & 1.000 & .227 & .210 & .506 \\
\hline & & Sig. (2-tailed) & .000 & . & .030 & .041 & .000 \\
\hline & & $\mathrm{N}$ & 69 & 69 & 69 & 69 & 69 \\
\hline & Rasionalization & $\begin{array}{l}\text { Correlation } \\
\text { Coefficient }\end{array}$ & .350 & .227 & 1.000 & .120 & .228 \\
\hline & & Sig. (2-tailed) & .002 & .030 & . & .163 & .030 \\
\hline & & $\mathrm{N}$ & 69 & 69 & 69 & 69 & 69 \\
\hline & Capability & $\begin{array}{l}\text { Correlation } \\
\text { Coefficient }\end{array}$ & .325 & .210 & .120 & 1.000 & .738 \\
\hline & & Sig. (2-tailed) & .003 & .041 & .163 & . & .000 \\
\hline & & $\mathrm{N}$ & 69 & 69 & 69 & 69 & 69 \\
\hline & $\begin{array}{l}\text { Kecenderunga } \\
\mathrm{n}\end{array}$ & Correlation & .618 & .506 & .228 & .738 & 1.000 \\
\hline & Kecurangan & Coefficient & & & & & \\
\hline & & Sig. (2-tailed) & .000 & .000 & .030 & .000 & \\
\hline & & $\mathrm{N}$ & 69 & 69 & 69 & 69 & 69 \\
\hline
\end{tabular}

Sumber: Output pengolahan data dengan SPSS 25, 2018

Berdasarkan tabel tersebut, bermakna bahwa tingkat korelasi parsial (partial correlation) antara pressure dengan kecenderungan kecurangan akuntansi (fraud) yaitu sebesar $0,618(61,8 \%)$ yang menyatakan bahwa korealsinya kuat, antara opportunity dengan kecenderungan kecurangan akuntansi (fraud) yaitu sebesar $0,506(50,6 \%)$ menyatakan bahwa korelasinya cukup kuat, antara rasionalization dengan kecenderungan kecurangan akuntansi (fraud) yaitu sebesar $0,228 \quad(22,8 \%)$ menyatakan bahwa korelasinya lemah, antara capability dengan kecenderungan kecurangan akuntansi (fraud) yaitu sebesar $0,738(73,8 \%)$ yang menyatakan bahwa korelasinya kuat.

\section{Pengujian Hipotesis}

\section{Uji Simultan}

\section{Tabel 11 Uji F}

\section{ANOVA}

\begin{tabular}{|c|c|c|c|c|c|c|}
\hline & & Sum of Squares & $\mathrm{Df}$ & Mean Square & $\mathrm{F}$ & Sig. \\
\hline & Regression & 3250.877 & 4 & 812.719 & 41.921 & $.000^{\mathrm{b}}$ \\
\hline 1 & Residual & 1240.775 & 64 & 19.387 & & \\
\hline & Total & 4491.652 & 68 & & & \\
\hline
\end{tabular}

a. Dependent Variable: Kecurangan Akuntansi (Y)

b. Predictors: (Constant), Capability (X4), Rasionalization (X3), Opportunity (X2), Pressure (X1)

Sumber: Output pengolahan data dengan SPSS 25, 2018

Berdasarkan tabel 11 tersebut dapat diketahui bahwa hasil pengujian menggunakan uji $\mathrm{F}$, diperoleh nilani $\mathrm{F}_{\text {hitung }}$ sebesar 41,921, sedangkan nilai $F_{\text {tabel }}$ sebesar 2,515. Apabila $F_{\text {hitung dibandingkan }}$ dengan $F_{\text {tabel }}$ maka $F_{\text {hitung }}>F_{\text {tabel }}$ $(41,921>2,515)$ dengan nilai signifikan $F$ sebesar $0,00<0,05$. Hal ini berarti bahwa Ho ditolak dan Ha diterima. Kondisi ini bermakna bahwa Pressure, Opportunity, Rasionalization dan Capability secara 
simultan berpengaruh signifikan terhadap

kecenderungan kecurangan akuntansi

(fraud) pada SKPD Kota Sukabumi.

\section{Uji Parsial}

Tabel 12 Uji t

Coefficients $^{\mathrm{a}}$

\begin{tabular}{|c|c|c|c|c|c|c|}
\hline \multirow{2}{*}{\multicolumn{2}{|c|}{ Model }} & \multicolumn{2}{|c|}{$\begin{array}{l}\text { Unstandardized } \\
\text { Coefficients }\end{array}$} & \multirow{2}{*}{$\begin{array}{l}\text { Standardized } \\
\text { Coefficients } \\
\text { Beta }\end{array}$} & \multirow[t]{2}{*}{$\mathrm{T}$} & \multirow[t]{2}{*}{ Sig. } \\
\hline & & $B$ & Std. Error & & & \\
\hline \multirow{5}{*}{1} & (Constant) & -10.737 & 4.052 & & -2.650 & .010 \\
\hline & Pressure (X1) & .370 & .113 & .303 & 3.271 & .002 \\
\hline & Opportunity (X2) & .193 & .092 & .181 & 2.098 & .040 \\
\hline & Rasionalization (X3) & .014 & .106 & .009 & .134 & .894 \\
\hline & Capability (X4) & 1.151 & .133 & .600 & 8.640 & .000 \\
\hline
\end{tabular}

a. Dependent Variable: Kecurangan Akuntansi (Y)

3. Sumber: Output pengolahan data dengan SPSS 25, 2018

Berdasarkan tabel 4.71 tersebut dapat

\section{Uji t Variabel Rasionalization}

Hasil pengujian dengan menggunakan diketahui bahwa:

\section{Uji t Variabel Pressure}

Hasil pengujian dengan menggunakan uji t diperoleh nilai thitung untuk Pressure sebesar 3,271, sedangkan nilai $t_{\text {tabel }}$ sebesar 1,998. Apabila $t_{\text {hitung dibandingkan dengan }}$ $t_{\text {tabel }}$ maka $t_{\text {hitung }}>t_{\text {tabel }}(3,271>1,998)$ dengan tingkat signifikan sebesar 0,002 < 0,05 . Hal ini berarti bahwa Ho ditolak dan Ha diterima. Kondisi ini bermakna bahwa pressure secara parsial berpengaruh terhadap kecenderungan kecurangan akuntansi (fraud) pada SKPD Kota Sukabumi.

\section{Uji t Variabel Opportunity}

Hasil pengujian dengan menggunakan uji t diperoleh nilai thitung untuk Pressure sebesar 2,098, sedangkan nilai $t_{\text {tabel }}$ sebesar 1,998. Apabila thitung dibandingkan dengan $t_{\text {tabel }}$ maka $t_{\text {hitung }}>t_{\text {tabel }}(2,098>1,998)$ dengan tingkat signifikan sebesar 0,04 < 0,05 . Hal ini berarti bahwa Ho ditolak dan Ha diterima. Kondisi ini bermakna bahwa Opportunity secara parsial berpengaruh terhadap kecenderungan kecurangan akuntansi (fraud) pada SKPD Kota Sukabumi.

\section{Koefisien Determinasi}

Koefisien determinasi dilakukan untuk mengetahui besarnya kontribusi variabel pressure, opportunity, rasionalization dan capability terhadap kecenderungan uji t diperoleh nilai thitung untuk Pressure sebesar 0,134, sedangkan nilai $t_{\text {tabel }}$ sebesar 1,998. Apabila thitung dibandingkan dengan $t_{\text {tabel }}$ maka $t_{\text {hitung }}<\mathrm{t}_{\text {tabel }}(0,134<1,998)$ dengan tingkat signifikan sebesar 0,894< 0,05 . Hal ini berarti bahwa Ho diterima dan Ha ditolak. Kondisi ini bermakna bahwa rasionalization secara parsial tidak berpengaruh terhadap kecenderungan kecurangan akuntansi (fraud) pada SKPD Kota Sukabumi.

\section{Uji t Variabel Capability}

Hasil pengujian dengan menggunakan uji t diperoleh nilai thitung untuk Pressure sebesar 8,640 , sedangkan nilai tabel sebesar 1,998. Apabila thitung dibandingkan dengan $t_{\text {tabel }}$ maka $t_{\text {hitung }}>t_{\text {tabel }}(8,640>1,998)$ dengan tingkat signifikan sebesar $0,000<0,05$. Hal ini berarti bahwa Ho ditolak dan $\mathrm{Ha}$ diterima. Kondisi ini bermakna bahwa capability secara parsial berpengaruh terhadap kecenderungan kecurangan akuntansi (fraud) pada SKPD Kota Sukabumi.

kecurangan akuntansi (fraud). Nilai determinasi menunjukkan seberapa besar prosentase model regresi mampu menjelaskan variabel dependen. Batas nilai $\mathrm{R}^{2}$ adalah $0 \leq \mathrm{R}^{2} \geq 1$ sehingga apabila $\mathrm{R}^{2}$ 
sama dengan nol (0) berarti variabel tidak bebas tidak dapat dijelaskan oleh variabel bebas secara serempak, sedangkan bila $\mathrm{R}^{2}$ Tabel 12 Koefisien Determinasi $\mathbf{R}^{2}$

\section{Model Summary ${ }^{b}$}

\begin{tabular}{lllll}
\hline Model & R Square & Adjusted R Square & $\begin{array}{l}\text { Std. Error of the } \\
\text { Estimate }\end{array}$ \\
\hline 1 & $.851^{\text {a }}$ & .724 & .706 & 4.403 \\
\hline a. Predictors: (Constant), Capability & $(\mathrm{X} 4)$, Rasionalization & $(\mathrm{X} 3)$, Opportunity & $(\mathrm{X} 2)$, \\
Pressure (X1) & & &
\end{tabular}

Berdasarkan tabel 4.71 diatas, diperoleh angka $\mathrm{R}^{2}$ ( $R$ square) Sebesar 0.724 atau $(72,4 \%)$. Hal ini menunjukan bahwa kontribusi pressure, opportunity, rasionalization dan capability terhadap kecenderungan kecurangan akuntansi (fraud) sebesar $72,4 \%$ sedangkan sisanya $27,6 \%$ dipengaruhi oleh variabel lain yang tidak dimasukan dalam model penelitian ini. Standard Error of the Estimate adalah suatu ukuran banyaknya kesalahan model regresi delam memprediksi nilai Y. Dari hasil regresi di dapat nilai 4,403 satuan, hal ini berarti banyaknya kesalahan dalam prediksi kecenderungan kecurangan akuntansi (fraud).

\section{Pembahasan}

\section{Karakteristik Responden}

Jumlah responden yang dijadikan sampel adalah 88 responden yang diambil dari SKPD Kota Sukabumi yang terdiri dari 17 Dinas, 2 Kantor dan 2 badan. Masing masing responden memiliki jabatan yaitu diantaranya Kepala Dinas, Kepala Kantor, Kepala Badan, Sekretaris, Kasubag Keuangan dan staff keuangan. Kuesioner yang disebar dalam penelitian ini sebanyak 88 namun yang hanya kembali yatiu 69 kuesioner. Karakteristik responden dalam penelitian ini didominasi oleh perempuan sebanyak 44 orang dengan latar belakang pendidikan Sarjana, masa kerja 2-3 tahun dan jabatan pekerjaan sebagai kasubag keuangan.

\section{Uji F}

Berdasarkan hasil uji $\mathrm{F}$ menunjukan bahwa pressure, opportunity, rasionalization dan capability berpengaruh sama dengan 1 berarti variabel bebas dapat menjelaskan variabel tidak bebas secara serempak. terhadap kecenderungan kecurangan akuntansi (fraud). Hal ini menunjukan adanya kebenaran atas teori yang dikemukakan oleh cressey dan wolf hermanson bahwa seseorang dapat melakukan kecurangan (fraud) karena adanya pressure, opportunity, rasionalization atau disebut fraud triangle. Kemudian ditambahkan oleh wolf hermanson dengan kemampuan (capability).

\section{Uji t}

\section{Pengaruh Pressure terhadap Kecenderungan Kecurangan Akuntansi (Fraud)}

Berdasarkan hasil uji parsial pressure berpengaruh terhadap kecenderungan kecurangan akuntansi (fraud). Tanggapan responden mengenai pengaruh pressure terhadap kecenderungan kecurangan akuntansi (fraud) pada umumnya adalah setuju, hal ini menunjukan bahwa jika pressure dalam sebuah instansi pemerintahan ada maka dapat menimbulkan terjadinya kecurangan. Adanya pengaruh pressure terhadap kecurangan akuntansi sesuai dengan teori yang dikemukakan oleh cressey bahwa pressure (tekanan) menjadi faktor pendorong seseorang melakukan kecurangan (fraud).

2. Pengaruh Opportunity terhadap Kecenderungan Akuntansi (Fraud)

Berdasarkan hasil uji parsial opportunity berpengaruh terhadap kecenderungan kecurangan akuntansi (fraud). Tanggapan responden mengenai opportunity berpengaruh terhadap 
kecenderungan kecurangan akuntansi (fraud) pada umumnya adalah setuju, hal ini menunjukan bahwa jika terdapat opportunity (kesempatan) dalam instansi pemerinthan, maka dapat menimbulkan adanya kecurangan (fraud) . Adanya pengaruh opportunity terhadap kecurangan sesuai dengan teori yang dikemukakan cressey bahwa opportunity (kesempatan) menjadi faktor pendorong seseorang melakukan fraud.

\section{Pengaruh Rasionalization terhadap} Kecenderungan Kecurangan Akuntansi (Fraud)

Berdasarkan uji parsial, rasionalization tidak berpengaruh terhadap kecenderungan kecurangan akuntansi (fraud) pada SKPD Kota Sukabumi. Hal ini karena banyaknya tanggapan responden yang kurang setuju dengan pernyataan-pernyataan mengenai rasionalization. Sebab rasionalization seorang yang berbuat kecurangan, tidak dapat diukur, karena rasionalization merupakan kesadaran atas pemikiran pembenaran atas perbuatan kecurangan yang dilakukan seseorang disamping itu, alasan tidak berpengaruhnya rasionalization terhadap kecurangan akuntansi (fraud) pada SKPD Kota Sukabumi karena responden memiliki latar belakang pendidikan yang tidak sesuai dengan pekerjaan responden sehingga responden kurang memahami apa yang disampaikan dalam instrument pernyataan dalam penelitian ini.

\section{Pengaruh Capability terhadap Kecenderungan Kecurangan Akuntansi (Fraud)}

Berdasarkan uji parsial, capability berpengaruh terhadap kecurangan akuntansi. Tanggapan responden mengenai capability berpengaruh terhadap kecenderungan kecurangan akuntansi (fraud) pada umumnya adalah setuju, hal ini membenarkan teori yang dikemukakan Wolf Hermanson mengenai fraud diamond, yaitu capability (kemampuan) atau seseorang yang memiliki wewenang dalam instansi memiliki peluang besar dalam melakukan tindakan kecurangan.

\section{Koefisien Determinasi}

Berdasarkan hasil koefisien determinasi Sebesar 0.724 atau $(72,4 \%)$. Hal ini menunjukan bahwa kontribusi pressure, opportunity, rasionalization dan capability terhadap kecenderungan kecurangan akuntansi (fraud) sebesar $72,4 \%$ sedangkan sisanya $27,6 \%$ dipengaruhi oleh variabel lain yang tidak dimasukan dalam model penelitian ini.

\section{Variabel paling Dominan}

Berdasarkan hasil korelasi parsial dapat disimpulkan bahwa variabel paling dominan adalah capability dengan nilai correlation paling besar diantara variabel lain yaitu sebesar $0,738(73,8 \%)$ bermakna bahwa capability memiliki pengaruh paling besar terhadap kecenderungan kecurangan akuntansi (fraud) pada SKPD Kota Sukabumi.

\section{KESIMPULAN}

Berdasarkan hasil pengujian, pengolahan dan analisis data yang telah dilakukan dan pembahasan yang telah dijelaskan, serta tujuan dari penelitian ini yaitu untuk mengetahui pengaruh pressure, opportunity, rasionalization dan capability terhadap kecenderungan kecurangan akuntansi (fraud) pada SKPD Kota Sukabumi, maka dapat diambil kesimpulan dari hasil peneltian tersebut sebagai berikut:

1. Karakteristik responden dalam penelitian ini yaitu didominasi oleh perempauan dengan latar belakang pendidikan sarjana, dengan masa kerja antara 2 s/d 3 tahun dan memiliki jabatan sebagai kasubag keuangan/staff keuangan.

2. Pressure, opportunity, rasionalization dan capability secara simultan berpengaruh terhadap kecenderungan kecurangan akuntansi (fraud) pada SKPD Kota Sukabumi.

3. Pressure, opportunity dan capability secara parsial berpengaruh terhadap kecenderungan kecurangan akuntansi (fraud), kecuali rasionalization secara parsial tidak berpengaruh terhadap 
kecenderungan kecurangan akuntansi (fraud) pada SKPD Kota Sukabumi.

4. Variabel yang paling dominan diantara Pressure, opportunity, rasionalization dan capability adalah variabel capability yang memiliki nilai beta lebih besar dari variabel lain dan tingkat signifikan lebih kecil dibanding variabel lain.

\section{SARAN}

Berdasarkan hasil pembahasan serta, maka terdapat beberapa saran yang dapat diberikan penulis yaitu sebagai berikut:

1. Instansi Pemerintah Kota Sukabumi perlu menghindari akan adanya peluang dalam perbuatan fraud, seperti meningkatkan pengendalian internal, memberikan pengawasan yang ketat, memberikan hukuman yang sesuai pada pelaku fraud sehingga dapat memberikan efek jera dan bekerja sesuai dengan latar belakang pendidikan dan tupoksi masing-masing jabatan. Disamping itu bonus atau reward perlu diberikan kepada pegawai yang taat, guna untuk memberikan kepuasan kerja terhadap pegawai. Sehingga dapat menghindari terjadinya kecurangan akuntansi (fraud) pada SKPD Kota Sukabumi.

2. Untuk peneliti selanjutnya disarankan agar melengkapi metode dan wawancara untuk meningkatkan kualitas jawaban dari responden. Dan sebaiknya menggali lebih banyak lagi mengenai faktor-faktor penyebab terjadinya kecurangan (fraud) sehingga dapat memberikan pengaruh yang jauh lebih besar yang berguna untuk tindakan pencegahan terjadinya kecurangan (fraud) terhadap suatu pemerintahan atau instansi.

\section{DAFTAR PUSTAKA}

Abdul Halim. (2003). Auditing (Jilid 1). UPP AA YKPN.Yogyakarta.
Abdullahi Rabiu, Mansoor Nurhayati. 2015. “Fraud Triangle Theory and Fraud Diamond Theory. Understanding the Convergent and Divergent ForFuture Research". Jurnal Internasional Universiti Sultan Zainal Abidin. Malaysia.

ACFE. 2009. Fraud Examiners Manual. P.37

Agoes, Sukrisno. 2016. Auditing. Salemba Empat. Jakarta.

.2014. Auditing. Buku Kedua .Salemba Empat. Jakarta..

Arens A.Alvin, Elder J. Randal, Beasley S. Mark. 2008. Auditing dan Jasa Assurance. Erlangga. Jakarta.

Arles, Leardo. 2014. Faktor - Faktor Pendorong Terjadinya Fraud : Predator vs. Accidental Fraudster Diamond theory Refleksi Teori Fraud Triangle (Klasik). Kajian Teoritis. Universitas Riau.

Baz, Rayaan. Samsudin, S. Rose. Ahmad, Popoola. Capability Component of Fraud and Fraud Prevention in the Saudi Arabian Banking Sector. 2016. International Journal of Economics and Financial Issues. University Utara Malaysia.

Gbgi,D.O, Adebisi J.F . 2013. The New Fraud Dioamond Model. International Journal Accounting. Kogi State University. Anyigba, Nigeria.

Ghozali, Imam. 2011. Aplikasi Analisis Multivariate dengan Program IBM SPSS 19 (edisi kelima). Universitas Diponegoro. Semarang.

Gusti Agung ,Yudistira. 2017. Pengaruh Aspek Tekanan, Penegakan Peraturan, Rasionalisasi dan Wewenang Pegawai Terhadap Fraud. Jurnal Akuntansi 
Universitas Pendidikan Ganesa. Singaraja.

Hendra, V. Santana, Y. Ghandatama, L. 2014. “Fraud Triangle". Jurnal Ekonomi. Universitas Surabaya.

Husmawati, Pera. 2017. "Analisi Fraud Pentagon dalam Mendeteksi Kecurangan Laporan Keuangan". Skripsi. Kementrian Riset Teknologi dan Politeknik Negeri Padang.

Indriani, Suroso, Maghfiroh. 2014. "Penerapan Konsep Diamond Fraud dalam Mendeteksi Perilaku Fraud". Jurnal Akuntansi. Universitas Jenderal Soedirman.

Kassem R, Higson. A.W. 2012. "The New Fraud Triangle Model”. Jurnal Internasional, Loughborough University. United Kingdom.

Lind A. Douglas, Marchal G. William, Wathen A. Samuel. 2017. TeknikTeknik Statistika dalam Bisnis dan Ekonomi. Salemba Empat. Jakarta.

Priantara, Diaz. 2013. Pemeriksaan dan Penyidikan Pajak. Djambatan. Jakarta.

Pristiyanti. 2012. Persepsi Pegawai Instansi Pemerintah Mengenai Faktor-Faktor yang Mempengaruhi Fraud di Sektor Pemerintahan. Jurnal Akuntansi. Semarang.

Priyatno, Duwi. 2011. Buku Saku Analisis Statistik Data SPSS. Mediakom. Yogyakarta.

Purwanto, Edy. Mulyadi. Anwar Choirul. 2017. "Kajian Konsep Diamond Fraud Theory dalam Menunjang Efektivitas Pengadaan Barang dan Jasa di Pemerintah Kota Bogor". Jurnal Akuntansi. Universitas Pancasila,
Universitas Negeri Jakarta. Jakarta.

Putri, Anisa. 2016. (Fraud) Kecurangan Laporan Keuangan. Jurnal Akuntansi.

Rachmat Syafie'I, Al-Hadist. 2003. Aqidah, Ahklak, Sosial dan Hukum. Cetakan II Revisi. Pustaka Setia. Bandung.

Rahmaidha, Rizqy. 2016. Pengaruh Keefektifan Pengendalian Internal, Ketaatan Aturan Akuntansi dan Kepuasan Kerja Terhadap Kecurangan Akuntansi. Jurnal Akuntansi. Magelang.

Rama, Dasaratha V \& Jones, Frederick I. 2008. Sistem Informasi Akuntansi. Salemba Empat. Jakarta

Romney B. Marshal, Steinbart, Jhon Paul. 2016. Sistem Informasi Akuntansi. Salemba Empat. Jakarta

Ruankew, Thanasak PhD. 2016. Beyond the Fraud Diamond. International Journal of Business Management and Economic Research(IJBMER). Colorado State University Global Campus. Colorado, United States.

Saifuddin, Azwar, 2004, "Reliabilitas dan Validitas", Cetakan kelima, Pustaka Pelajar Offset, Yogyakarta.

Sanusi, Anwar, 2017 "Metode Penelitian Bisnis", Cetakan ketujuh, Salemba Empat. Jakarta.

Sekaran, Uma. 2003. Research Method For Business : A Skill-Building Approach, Third Edition, New York : Jhon Wiley \& Sons Inc.

Shelton, M. Austin.2014. “Analysis of Capabilities Attributed to the 
Fraud Diamond". East Tennessee

State University. Amerika Serikat.

Shintadevi, Farizqa. Pengaruh Keefektifan Pengendalian Internal, Ketaatan Aturan Akuntansi, dan Kesesuaian Kompensasi Terhadap Kecenderungan Kecurangan Akuntansi dengan Perilaku Tidak Etis Sebagai Variabel Intervening. Jurnal Akuntansi. Yogyakarta.s

Sihombing.2014. "Analisis Fraud Diamond dalam Mendeteksi Financial Statement Fraud : Studi Empiris pada Perusahaan Manufaktur yang Terdaftar di Bursa Efek Indonesia (BEI)".Skripsi Universitas Diponegoro. Semarang.

Sugiyono. 2012. Memahami Penelitian Kualitatif. Alfabeta. Bandung

2013. Metode Penelitian Kombinasi (Mixed Methods). Cetakan Ketiga. Alfabeta. Bandung.

Susandra, F. Susanti, S. Analisis FaktorFaktor yang Mempengaruhi Kecenderungan Fraud Pada SKPD di Kota Bogor. Jurnal Akunida. Universitas Djuanda. Bogor.

Thoyibatun, Siti. 2009. Faktor-Faktor yang Berpengaruh Terhadap Perilaku Tidak Etis dan Kecenderungan Kecurangan Akuntansi Serta Akibatnya Terhadap Kinerja Organisasi. Jurnal Ekonomi dan Keuangan Universitas Negeri Malang.

Widjaja, Amin. 2013. Corporate Fraud dan Internal Control. Edisi Keempat. Harvarindo. Jakarta.

Wilopo. 2006. Pengaruh Keefektifan Pengendalian Internal, Kesesuaian Kompensasi dan Ketaatan Aturan Akuntansi
Terhadap Kecenderungan Kecurangan Akuntansi pada BUMN di Indonesia. Thesis. Universitas Airlangga.

Wolfe, T.David, Hermanson R. Dana. 2004. "The Fraud Diamond: Considering the Four Elements of Fraud". Jurnal Internasional. Kennesaw State University. Amerika Serikat.

Zainal, Rizky. 2013. Pengaruh Efektivitas Pengendalian Internal, Asimetri Informasi, dan Kesesuaian Kompensasi Terhadap Kecenderungan Kecurangan Akuntansi. Skripsi Sarjana Universitas Negeri Padang.

http://www.hukumonline.com (diakses 1 April 2018, 10:05)

https://antikorupsi.org (Indonesian Corruption Watch, diakses 07 Maret 2018, 09:15)

http://jabar.pojoksatu.id (diakses 10 Maret 2018, 20:10)

http://www.bpk.go.id (diakses 11 Maret 2018, 19:45)

http://www.djpk.depkeu.go.id (diakses 12 Maret, 19:10)

http://www.news.okezone.com (diakses 15 April 14:15)

http://portal.sukabumikota.go.id (diakses 30 Maret 19:20) 